\title{
Total Quality Management Practices and Performance of Deposit Money Banks (DMBs) in Nigeria
}

\author{
Asenge, Emmanuel Lubem ${ }^{1 *}$, Adudu, C.A. ${ }^{2}$, Torough, S.M ${ }^{2}$ \\ ${ }^{1}$ Department of Business Management, Benue State University, Makurdi-Nigeria \\ 2Department of Business Administration, Federal University of Agriculture, Makurdi
}

*Corresponding Author

Asenge, Emmanuel Lubem

\section{Article History}

Received: 07.12.2019

Accepted: 15.12 .2019

Published: 25.12 .2019

\begin{abstract}
This study examined the effect of total quality management practices on performance deposit money banks in Nigeria. The study focused on selected deposit money banks in Makurdi metropolis, Benue State, Nigeria. The study specifically examined the effect of top management commitment, employee involvement, customer focus and process management on performance of deposit money banks in Nigeria. A survey design was adopted for the study and questionnaire was used for data collection. The population of the study consists of 32 management staff of Makurdi metropolis and a census sampling method was adopted. Regression analysis was used for test of hypotheses at 0.05 significance level. Findings of the study revealed that all the independent variables (top management commitment, employee involvement, customer focus and process management) have significant effect on performance of deposit money banks in Nigeria. It recommended that management of deposit money banks should develop policies that require senior management to be involved in quality improvement efforts since this ensures success of the efforts and improved bank performance.
\end{abstract}

Keywords: Total Quality Management, Organizational Performance, Top Management Commitment, Employee Involvement, Customer Focus, Process Management.

\section{INTRODUCTION}

Globalization, changes in technology, intense competition and increase in customers' demands and expectations for quality products and services have dramatically changed the business environment. These changes have forced many organizations to espouse quality management tools such as Total Quality Management (TQM), Balanced Scorecard and Business Process Reengineering as a way of improving the services delivered to their customers. Total Quality Management (TQM) is a business management strategy aimed at embedding awareness of quality in all organizational processes. Total quality management involves an organizational cultural commitment to satisfying customers through the use of an integrated system of tools, techniques and training. It also involves the continuous improvement of organizational processes, resulting in high-products and services [1].

It involves making unvarying effort to identify what a customer wants periodically and determining how to cater for them. This is because customers' needs, desires and wants normally change over time, in relation to changes which may occur in the key aspects of the environment such as social, political, economic and technological changes. It necessitates an organisation to uphold excellence in all aspects of its business by ensuring that defects and wastes are eliminated from operations. Total Quality Management practices have been identified by different scholars. Bon and Mustafa [2] identified the seven practices of TQM to include; top management leadership, employee involvement, employee empowerment, customer focus, training, information analysis, and continuous improvement. Zehir et al., [3] in their study identified eight dimensions of TQM; leadership management, employee management, customer focus, factual approach to decision making, supplier management, continual improvement, system approach to management and process management. These processes help in improving the performance of organizations regarding quality of services, customer satisfaction and profitability [4].

In addition, quality management practices such as customer focus, top management commitment or leadership, process management and employee involvement are increasingly becoming important, particularly in the service sector in an effort to meet

Copyright @ 2019: This is an open-access article distributed under the terms of the Creative Commons Attribution license which permits unrestricted use, distribution, and reproduction in any medium for non commercial use (NonCommercial, or CC-BY-NC) provided the original author and source are credited. 
customers' expectations. The implementation of total quality management practices in the service sector generates improved products and services, more satisfied customers and employees, reduced costs, improved financial performance, enhanced competitiveness and increased productivity. In order to effectively measure performance attributed to the quality management practices, organizations must define their quality parameters [5]. Performance results from what organizations do regarding quality management practices and the results they achieve in several types of outcomes. Promoting superior quality and innovation should be one of the most important priorities in any organization [6]. Service quality can improve the competitiveness of an organisation, and the organisation can gain a competitive advantage and differentiate itself from others by improving service quality [7].

The banking sector is facing unstable financial times, related to liquidity, inflation, exchange rate, credit, loans, cash flow and interest rate, so banks need to establish procedures and tools in order to confront these challenges enhance their performance and survive through economic hardships. The banking sector is the largest sector in the service industry that serves the needs of different categories of people. Al-Marri et al., [8] established that TQM is essential for banking sector to improve profitability, expand the customer base and increase customer loyalty. Many banks in Nigeria have a vested interest in implementing TQM practices. While TQM has been heavily researched in recent years, researchers have used different dimensions to explain the concept. Few studies have been carried out on the relationship between TQM practices and performance of the Nigerian banking industry. This study tries to fill this gap by investigating the effect of Total Quality Management Practices on performance of the Nigerian banking industry.

\section{ObJectives OF THE Study}

The main objective of this study was to examine the effect of total quality management practices on performance of the Nigerian banking industry. The specific objectives of the study were to:

- Determine the effect of top management commitment on performance of deposit money banks in Nigeria;

- Ascertain the effect of employee involvement on performance of deposit money banks in Nigeria;

- Examine the effect of customer focus on performance of deposit money banks in Nigeria;

- Assess the effect of process management on performance of deposit money banks in Nigeria.

\section{Research Hypotheses}

The following null hypotheses have been formulated for this study:

- Top management commitment has no significant effect on performance of deposit money banks in Nigeria

- Employee involvement has no significant effect on performance of deposit money banks in Nigeria

- Customer focus has no significant effect on performance of deposit money banks in Nigeria

- Process management has no significant effect on performance of deposit money banks in Nigeria

\section{LITERATURE REVIEW}

\section{Concept of Total Quality Management (TQM)}

Total Quality Management (TQM) is a system of behaviour which embraces everyone within an organisation and which determines their relationships with the customers, suppliers, competitors, society and the environment. TQM is the state of an organization in which all the activities of all functions are designed and carried out in such a way that all external customer requirements are met while reducing internal time and cost, and enhancing the workplace climate. Demirbag et al., [9] define TQM as a holistic management philosophy aimed at continuous improvement in all functions of the organization and satisfaction of customers' needs and requirements by providing quality services under the leadership of top management. TQM is therefore significant because its implementation brings about positive impact on the organization and its employees. In the words of Oakland [10], Total Quality Management (TQM) is a comprehensive approach that helps organizations to improve their competitiveness as well as their flexibility through planning, organizing and understanding each activity, and involving everyone at each level. Total Quality Management is defined in this study as a set of management practices that help to instill awareness of quality principles through the organization by ensuring that customer requirements or expectations are consistently met.

\section{Dimensions of Total Quality Management}

Total quality management practices used in this study include top management support, employee involvement, customer focus and process management.

\section{Top Management Support}

Top management support is the degree of acceptance of quality responsibility by top management, and participation in quality improvement efforts and monitoring this application. This includes, identifying culture for quality, commitment for quality improvement, guiding and affecting the company in setting quality strategy direction and sustaining effective leadership through the organization. They set policy, plan strategy and launch tactics for staff to execute [11]. The commitment of top management is topmost in the implementation of total quality management. Mehra et al., [12] asserted that top management provides both the physical and leadership needs of the organization and most organizational changes and training needs require top management approval. In addition, top management behavior signals to all employees the importance of TQM which include coaching and facilitating. 


\section{Employee Involvement}

Employee involvement is necessary for the success of every organization. This can be achieved through using of work teams, looking for opportunities to raise the level of employee's competence, sharing information and experiences between the teams and groups and focusing on employee's motivation and loyalty. Involvement of employees in quality enhancement activities such as: teamwork, employee suggestions, and employee commitment enhances organizational performance [13]. Abbas and Yahiya [11] in their study showed that employee enhancement activities include education, training, teamwork, employee suggestions and employee commitment.

\section{Customer Focus}

Customer focus refers to the degree to which an organization is able to serve its clients' needs and expectations. This is done by determining the customer's needs, as well as to receive feedback on the extent to which those needs are being met and through involving the customer in the product design and development process, and focusing in achieving greater customer satisfaction. Organizations rely on their customers, so they must understand the current and future needs, and achieve their needs, and work to exceed their expectations. This is achieved by carrying out research and understanding all the needs and expectations of customers regarding products, services and reliability [14].

\section{Process Management}

Process management is defined as the process of planning and administering the activities necessary to achieve a high level of performance in key organizational processes and identifying opportunities for improving quality and operational performance, and ultimately, customer satisfaction [15]. Common organizations processes include acquiring customer needs; strategic planning; conducting research and development; purchasing; developing new product or service; fulfilling customer expectations; managing information; measuring and analyzing performance and training employees. In order to improve quality, many organizations have created quality teams that are required to develop specific plans and set goals that will have a measurable impact on an organization's key area of customer satisfaction [16]. The focus should be on how best to design, manage and improve processes in order to fully satisfy, and generate increasing value for customers and other stakeholders [17].

\section{Concept of Organizational Performance}

Organizational performance according to Evans and Lindsay [15] refers to the recurring activities which establish organizational goals, monitor progress toward the goals, and make adjustments to achieve those goals more effectively and efficiently. Organizational performance is the result of factors such as work processes; team/group communication and interaction; corporate culture and image; policies; leadership; climate for innovation and creativity; and loyalty [7, 18].

In examining the relationship between quality principles and practices and performance, previous studies have used different performance measures such as financial, innovative, operational and quality performance. In this study two performance variables were used to measure organizational performances which are the satisfaction level which was measured by employee satisfaction, and operational performance results which was measured by operational efficiency.

\section{Total Quality Management Practices and Organizational Performance}

The degree of commitment and support that management takes in implementing a total quality environment is critical to the success of the organization. The quality and impact of leadership is critically important especially at every organization because the effectiveness of employees' performance is highly dependent on leadership. Kanji and Moura [19] in their study showed that the cooperation and commitment of leaders and subordinates in an organization is essential for the implementation of TQM and organizational performance. Total quality management practices such as employee involvement encourage participation of employees in decision making and it ensured that the right training is given to the right people. Training given to the right people has been proven to minimize the misuse of the tools and techniques [17]. Mutisya [20] in his study highlights those participatory measures such as team-working and high-involvement work practices demonstrate improvements in performance, but can also have less positive outcomes for employee and social well-being.

A strong link between the delivery of high quality goods and services and profitability through customer satisfaction has been established by Nganga [21]. In another study, Soltani [22] advocates that an organization must identify customer relationship to measure customer needs and expectations; involve customers in quality improvement and determine customer satisfaction which ultimately enhance performance of the organization. Nganga [21] also averred that to remain competitive, it is important that incoming information and changes in customer preferences are analyzed and understood Brahet et al., [18] noted that the effectiveness of process management implementation has been argued as one of the major dimensions of integrated quality efforts. Jaafreh and Alabedallat [23] asserted that the focus on process management results in the increase in the quality of outputs as well as decreasing the costs such as rework costs and waste costs. This in turn leads to improved overall bank performance.

\section{Theoretical Framework}

This study is anchored on Juran's Theory of Quality Management. Juan [24] proposed a strategic and structural approach to quality management where focus should be on delivering quality on each project. The theory summarizes quality management into 
three main steps known as the Quality Trilogy. The first segment is quality planning which involves creating an awareness of the need to improve and setting goals and plans on how to achieve the set goals. This means that the management has to be willing to commit to change. It also requires a highly trained and qualified staff. The second step is quality control which involves coming up with methods to test product and services for quality. Any deviation from the set standards means that the product will have to undergo changes and improvements. The final stage is quality improvement which is a continuous pursuit toward perfection.

Applying this theory to the understanding of why quality management is critical for firm performance, it is clear that Juran proposes that banks should focus on ensuring that each program and policy undertaken by the bank is delivered to the highest quality possible. The management of commercial banks in Nigeria should be on the fore front in implementing customer quality programmes that are constantly reviewed to ensure that they meet the continually growing and dynamic needs of customers as well as programme that will encourage the bank staff to continue working at optimal productivity.

The theory is relevant to the current study because it shows the importance of adopting quality management practices in order to ensure that banks improve their performance. Banks have to react to the environment by adopting new quality management practices since this will result in an alignment of the organizational objectives to the market needs and customer expectations.

\section{Methodology}

A survey design was adopted for this study. Surveys are mainly used in studies that have individual people as unit of analysis. This method is used because it allowed the researcher to collect different views of the respondents on the topic. The area covered by this study is Makurdi metropolis, Benue State. The population of the study consists of 32 management staff of Deposit Money Banks in Makurdi Metropolis (First Bank of Nigeria Plc, United Bank for Africa Plc and Guarantee Trust Bank Plc in Makurdi metropolis). The study considers only management staff since they were in a better position to understand the subject matter under investigation. A census sampling method was adopted and the entire serves as the sample for this study. This method is used since the target population is manageable. Questionnaire is used as the instrument for data collection. The questionnaire is considered appropriate because it makes collection of opinions and measurement of attitudes in a large population possible. Validity and reliability of the instrument were carried out to ensure consistency of the measurement instrument. A pilot test was conducted on 20 respondents before the final instrument was distributed to the participants. The result of the reliability test shows that all the constructs have Cronbach's alpha which is greater than 0.70 as recommended by Nunnally and Bernstein [25]. The result of the reliability was as follows: Top Management Commitment (0.892), Employee Involvement (0.880), Customer Focus (0.912), Process Management (0.905) and Performance (0.941). Both inferential and descriptive statistics were used for data analysis. Quantitative data from the questionnaire were coded and entered into the computer for computation of descriptive statistics. Descriptive statistics such as frequency and percentages were for data presentation and analysis while formulated hypotheses were tested using multiple regression.

\section{Variable/Model Specification}

This study conceptualizes the relationship between independent variables and dependent variables. The independent variable is conceptualized as TQM practices and was measured by the following constructs: top management commitment, employee involvement, customer focus and process management. The dependent variable on the other hand was operationalized as organizational performance whose constructs include employee satisfaction and operational efficiency. In this study bank performance is given as a function of Total Quality Management. The implicit form of the regression model is expressed thus:

$B P E=f(T Q M)$

Where;

BPE = Bank Performance (dependent variable)

TQM = Total Quality Management (independent variable)

The explicit form of the model can be stated thus:

$B P E=B_{0}+B_{1}(T M C)+B_{2}(E I N)+B_{3}(C U F)+B_{4}(P R M)+e$

Where:

TMC= Top Management Commitment

EIN= Employee Involvement

CUF= Customer Focus

$\mathrm{PRM}=$ Process Management

$\mathrm{B}_{0}=$ constant of the model.

$B_{1-4}=$ coefficients of the model.

$\mathrm{e}=$ disturbance terms or error term 


\section{Results AND Discussion \\ Demographic Attributes of Respondents}

The demographic attribute of respondents as shown in Table-1 revealed that, $71.9 \%$ of the respondents were males while $28.1 \%$ respondents were females. This implies that both male and female respondents participated in the survey. The distribution of the respondents by age shows that $11(34.4 \%)$ respondents were from the ages of $18-27,8(25.0 \%)$ respondents were between 28 and 37 years, $6(18.8 \%)$ respondents were from the age of $38-47$ years while $7(21.9 \%)$ respondents were 48 years and above. The distribution of respondents by educational qualification indicates that, $8(25.0 \%)$ respondents had OND/NCE, $14(43.7 \%)$ had HND/B.Sc while $10(31.3 \%)$ had MA/M.Sc. This implies that the participants who are employees of the banks surveyed were literate enough to understand the topic under investigation. The distribution of respondents by experience shows that, $28.1 \%$ of the respondents were from $1-5$ years, $31.3 \%$ were from $6-10$ years, and $21.9 \%$ were from $11-15$ years while $18.8 \%$ were over 15 years. This implies that the respondents had worked in the organization for many years and had enough experience to provide valid answers to the survey questions.

Table-1: Demographic Attributes of Respondents (n= 32)
\begin{tabular}{|c|c|c|}
\hline Attributes & Frequency & Percentage (\%) \\
\hline Gender & 23 & 71.9 \\
\hline Male & 9 & 28.1 \\
\hline Female & 11 & 34.4 \\
\hline Age \\
\hline $18-27$ & 8 & 25.0 \\
\hline $28-37$ & 6 & 18.8 \\
\hline $38-47$ & 7 & 21.9 \\
\hline 48 and above & 7 & 25.0 \\
\hline Educational Qualification \\
\hline OND/NCE & 8 & 43.7 \\
\hline HND/B.Sc & 14 & 31.3 \\
\hline MA/M.Sc & 10 & 28.1 \\
\hline Experience & 9 & 21.9 \\
\hline 1-5 years & 9 & 18.8 \\
\hline $6-10$ years & 10 & 7 \\
\hline $11-15$ years & 7 & 6 \\
\hline Over 15 years & 6 & \\
\hline
\end{tabular}

Source: Field Survey, 2019.

\section{Test of Hypotheses}

Regression analysis was used to determine the extent to which the Total Quality Management practices: top management commitment, employee involvement, customer focus and process management affect organizational performance. The result from the model summary shows that all the predictors account for $69.1 \%$ variation of organizational performance as represented by the $\mathrm{R}^{2}=$ .691 while the remaining $30.9 \%$ is accounted by other factors outside the regression model. The F- ratio (76.423) was significant $(\mathrm{P}<.05)$. The model significantly improved the ability to predict the effects of Total Quality Management practices on organizational performance. The model was modified to reflect the variables of this study:

The result from the regression model in Table-2 shows that the top management commitment indicates $(t=8.994, p=.000<$ $.05)$; employees' involvement $(t=2.508, p=.012<.05)$, customer focus $(t=2.832, p=.005<.05)$ and process management $(t=3.354$, $p=.001<.05)$. It further reveals that an increase in top management commitment by one unit will lead to $73.7 \%$ increase in organizational performance; an increase in employee involvement will lead to $13.2 \%$ increase in organizational performance and an increase in customer focus leads to $15.2 \%$ increase in organizational performance while a change in process management brings about $27.8 \%$ increase in organizational performance. This result implies that top management commitment has the most significant effect on the performance of the Nigerian banking industry. The four hypotheses were tested at 0.05 level of significance and the result shows that they were all significant since their $p$-values were less than 0.05 . The null hypotheses were therefore rejected and alternate hypotheses accepted respectively.

Table-2: Multiple Regression Model

\begin{tabular}{|l|l|l|l|l|l|l|l|}
\hline \multirow{2}{*}{} & \multicolumn{9}{|l|}{ Unstandardized Coefficients } & \multicolumn{2}{l|}{ Standardized Coefficients } & \multicolumn{2}{l|}{ Collinearity Statistics } \\
\cline { 2 - 9 } & $\mathbf{B}$ & Std. Error & Beta & $\mathbf{t}$ & Sig. & Tolerance & VIF \\
\hline (Constant) & .298 & .386 & & .777 & .000 & & \\
\hline Top Mgt Commitment & .737 & .082 & .777 & 8.994 & .000 & .303 & 1.300 \\
\hline Employees' Involvement & .132 & .022 & .233 & 2.508 & .012 & .526 & 1.902 \\
\hline Customer Focus & .152 & .054 & .272 & 2.832 & .005 & .245 & 1.562 \\
\hline Process Management & 278 & .083 & .302 & 3.354 & .001 & .279 & 1.325 \\
\hline
\end{tabular}




\begin{tabular}{|ll|}
\hline R Square & $=.691$ \\
\hline Adjusted R Square & $=.681$ \\
\hline Std. Error of the Estimate $=.40745$ & \\
\hline Durbin-watson & $=1.019$ \\
\hline F-Statistic & $=76.423$ \\
\hline df & $=4$ \\
\hline Sig. & $=.000$ \\
\hline Dependent Variable: Performance \\
\hline \multicolumn{2}{|c|}{ Source: Field Survey, 2019. }
\end{tabular}

\section{DISCUSSION OF FINDINGS}

Findings of the study revealed that there is a positive relationship between top management commitment towards quality management practices implementation and performance of the banking industry. This is in line with the results of Zhang [26] commitment and personal involvement is required from top management in creating and developing clear quality values and goals consistent with the objectives of the company. Kanji and Moura [19] and Pheng and Teo [27] also showed a significant relationship between top management commitment and organisational performance.

Findings of the study also revealed that there is a positive relationship between employee and performance of the banking industry. The study revealed that the employees of the selected banks were regularly trained which help to improve their technical skills to serve their clients better hence improve the performance of their banks. This result is in agreement with Otunga [17] who emphasized the importance of involving employees in affairs of the organization. Al-Shobaki et al., [28] also agreed that the involvement of employees in TQM practices in the banking sector leads to increased productivity and ability to compete in the global markets.

The result on the third objective indicates that there is a positive significant effect of customer focus on performance of the banking industry in Nigeria. The study established that the banks relied on customer records and feedback to improve their services which has improved their performance. This result corroborates previous studies by Soltani [22] whose study revealed that an organization must identify customer relationship to measure customer needs and expectations. Goetsch and Davis [29] emphasized that keeping employees in touch with customers is critical to forming a customer focus which positively affect the corporate performance.

Finally, findings of the study show that process management has a positive significant effect on performance of the banking industry in Nigeria. This is in line with Jaafreh and Al-abedallat [23] who noted that the focus on process management leads to improved bank performance regarding increase in the quality of outputs as well as decreasing the costs such as rework costs and waste costs. Brahet et al., [18] also share credence with similar findings.

\section{ConcLusion And ReCOMmendations CONCLUSION}

This study examined the effect of total quality management practices on performance of deposit money banks in Nigeria. Findings of the study established that there a significant relationship between total quality management practices implementation and performance of deposit money banks in Nigeria. The study concludes that commitment of senior management towards the process of identifying, adopting and implementing practices to improve quality in the banks results to corporate performance. The study also concludes that the involvement of employees through consultations and effective communication is important in bringing the needed changes in the organization. The study further concludes that the focus on customers and improvement in services offered to them is fundamental to the accomplishment of banks' objectives. Finally, the study concludes that the focus in improving diverse processes in the organization is an effective way of improving quality services rendered by banks.

\section{RECOMMENDATIONS}

Based on findings of the study and conclusion drawn, the following recommendations are made:

- Management of deposit money banks should develop policies that require senior management to be involved in quality improvement efforts since this ensures success of the efforts and improved bank performance.

- Management of banks should always involve employees in the process of identification and implementation of quality management practices through regular training to improve their productivity.

- Management of banks should intensify efforts in improving the quality of services delivered to customers to meet customer needs and expectations.

- Banks should ensure that they improve the efficiency of their daily processes which will bring accelerated development. 


\section{REFERENCES}

1. Bvuma, D. G., \& Russel, E. W. (2001). Alternative service delivery and public service transformation in South Africa. The International Journal of Public Sector Management, 14(3):241-264.

2. Bon, A., \& Mustafa, E. (2013). Impact of total quality management on innovation in service organizations: Literature review and new conceptual framework. Procedia Engineering, 53(1), 516-529.

3. Zehir, C., Ertosun, Ö., Zehir, S., \& Müceldilli, B. (2012). Total quality management practices' effects on quality performance and innovative performance. Procedia Engineering, 41, 273-280.

4. Boyne, G. A., \& Walker, R. M. (2002). Total quality management and performance. An evaluation of the evidence and lessons for research on public organizations. Public Performance \& Management Review, 26(2):111-131.

5. Hasan, M., \& Kerr, R. M. (2003).The relationship between Total Quality Management Practices and Organizational Performance in Service Organizations. The TQM Magazine, 15(4), 286-291.

6. Zhang, Z. H. (2000). Developing a model of quality management methods and evaluating their effects on business performance. Total Quality Management Journal, 11(1), 129-137.

7. Ellis, G. (2000). Organizational performance: balanced scorecard and human performance. Management Today, 16(8), 32-33.

8. Al-Marri, K., Ahmed, A. M. M. B., \& Zairi, M. (2007). Excellence in service: An empirical study of the UAE banking sector. International Journal of Quality and Reliability Management, 24(2), 164-176.

9. Demirbag, M., Tatoglu, E., Tekinkus, M., \& Zaim, S. (2006). An analysis of the relationship between TQM implementation and organizational performance. Journal of Manufacturing Technology Management, 17(6), 829-884.

10. Oakland, J. (2000). Total quality management - text with cases ( $2 \mathrm{n}$ ed.). Oxford: Butterworth Heinemann.

11. Abbas, A. S., \& Yahiya, A. (2014). The Impact of Total Quality Management Practices on Innovation Performance and Organizational Performance. Indian Journal of Fundamental and Applied Life Sciences, 4(4), 2050-2057.

12. Mehra, T., Osseo-Asare, A. E., Longbottom, D., \& Murphy, W. D. (2001). Leadership best practices for sustaining quality in UK higher education from the perspective of the EFQM Excellence Model. Quality Assurance in Education, 13(2), 148-170.

13. Alamutu, S. A., Hotepo, O. M., Oyeobu, A. J., \& Nwatulegwu, B. I. (2012). An evaluation of total quality management practices on business performance of the Nigerian telecommunications sector: a case study of MTN Nigeria Limited. Proclaim ICCEM, 2(3):155:166.

14. Djerdjour, M., \& Patel, R. (2000). Implementation of quality programs in developing countries: a Fiji islands case study. Total Quality Management, 11(1), 25-44.

15. Evans, J. R., \& Lindsay, W. M. (2008). Managing for quality and performance excellence. Seventh ed. Canada: Thomson.

16. Al-Damen, R. A. (2017). The impact of Total Quality Management on organizational performance Case of Jordan Oil Petroleum Company. International Journal of Business and Social Science, 8(1), 192-202.

17. Otunga, M. S. (2007). A framework for measuring quality in engineering education. Total Quality Management, 9(6), $501-518$.

18. Brysland, A., \& Curry, A. (2001). Service improvements in public services using SERQUAL. Managing service Quality, 11(6), 389-401.

19. Kanji, G., \& Moura, P. (2003). Sustaining healthcare excellence through performance measurement. Total Quality Management and Business Excellence, 14(3), 269-289.

20. Mutisya, R. A. (2010). An Empirical Assessment of the Influence of Quality Dimensions on Organizational Performance. International Journal of Production Research, 34(7), 43-62.

21. Nganga, S. I. (2010). Financing Higher Education and the Quality of Education in Tertiary Institutions in Kenya. A Journal of the KIM School of Management, 1(2), 45-58.

22. Soltani, E. (2005). Top management: a threat or an opportunity to TQM?, Quality Management. South African Publishers, Natal.

23. Jaafreh, P., \& Al-abedallat, K. (2013). An application of total quality management for Thai communities knowledge management system. Paper presented at the Fourth International Conference on e- Business.

24. Babor, T. F., de la Fuente, J. R., Saunders, J., \& Grant, M. (2001). The Alcohol Use Disorders Identification Test: Guidelines for use in.

25. Berle, J. Ø., Aarre, T. F., Mykletun, A., Dahl, A. A., \& Holsten, F. (2003). Screening for postnatal depression: Validation of the Norwegian version of the Edinburgh Postnatal Depression Scale, and assessment of risk factors for postnatal depression. Journal of affective disorders, 76(1-3), 151-156.

26. Zhang, Q., Chang, J., Wang, T., \& Xu, Y. (2007). Review of biomass pyrolysis oil properties and upgrading research. Energy conversion and management, 48(1), 87-92.

27. Pheng, L. S., \& Teo, J. A. (2004). Implementing total quality management in construction firms. Journal of management in Engineering, 20(1), 8-15.

28. Al-Shobaki, G., Ang, Y., Lee, V., \& Tan, B. (2010). The impact of TQM practices on learning organization and customer orientation: a survey of small service organizations in Malaysia. International Journal of Services, Economics and Management 2(2), 134-149.

29. Goetsch, D. L., \& Davis, S. B. (2010). Quality Management for organizational excellence: introduction to Total Quality Management. 7th Ed. UK: Pearson. 